Article

\title{
The Deterritorialised Muslim Convert in Post-Communist Eastern European Cinema
}

DE DE GRUYTER

OPEN

EWA MAZIERSKA, University of Central Lancashire, United Kingdom; email: ehmazierska@uclan.ac.uk LARS KRISTENSEN, University of Skövde, Sweden; email: lars.kristensen@his.se EVA NÄRIPËA, Estonian Academy of Arts, Film Archives of The National Archives; email: eva.naripea@artun.ee 


\section{ABSTRACT}

This article analyses the Muslim convert as portrayed in three post-communist Eastern European films: Vladimir Khotinenko's A Moslem (Мусульманин, Russia, 1996), Jerzy Skolimowski's Essential Killing (Poland/Norway/ Ireland/Hungary/France, 2010), and Sulev Keedus's Letters to Angel (Kirjad Inglile, Estonia, 2011). Although set in different periods, the films have their origins in Afghanistan and then move to European countries. The conversion to Islam happens in connection to, or as a consequence of, different military conflicts that the country has seen. The authors examine the consequences the characters have on their environment, using Gilles Deleuze and Félix Guattari's concept of deterritorialisation, understood as an opportunity to produce political and cultural change. Resettling from one religion and place into another means breaking up structures that need to be reassembled differently. However, these three films seem to desire deterritorialisation and resettlement for different reasons. In A Moslem, national structures need to be reset since foreign Western values have corrupted the post-communist Russian rural society. In Essential Killing, it is the Western military system of oppression that cannot uphold the convert and his values. Lastly, in Letters to Angel, the convert exposes the hollowness of post-communist capitalism. The Muslim converts in these films are subtle reminders that we can all reinvent ourselves.

\section{INTRODUCTION}

To date, the screen representations of Islamic identity in Eastern European cinema have drawn relatively little academic interest (exceptions being, e.g., Ostrowska 2011, Ladegaard 2013, Mazierska 2014, Ludewig forthcoming). This article is an attempt to address this gap to a certain extent by investigating representations of Muslim converts in Eastern European cinema. Our study focuses on three case studies - A Moslem (Мусульманин, Russia, 1996) by Vladimir Khotinenko, Essential Killing (Poland/Norway/Ireland/Hungary/ France, 2010) by Jerzy Skolimowski, and Letters to Angel (Kirjad Inglile, Estonia, 2011) by Sulev Keedus. For the purpose of building a context for these post-Soviet works, we will provide a brief overview of the migration discourses within which Muslim characters have played a role, as well as a short survey of the earlier appearances of Muslim 
characters on the (mainly) Soviet screen. Our analysis of Muslim identities in these post-communist and, on two occasions also clearly transnational, films is framed by Deleuzo-Guattarian concepts of "becoming-minor" (Deleuze, Guattari [1975] 1986) and deterritorialisation (Deleuze, Guattari [1972] 1983).

One of the dominant themes that have preoccupied film studies in the post-communist era has been that of migration. A variety of publications have dealt with the representation of migrants and diasporic subjects, as well as with the increased transnational mobility of films and filmmakers, in an effort to capture a particular European identity. While we will limit ourselves to looking at representations and not the mobility of the filmmakers in this study, the literature in the field often includes both approaches to migration. One of the first accounts of these journeys across national borders was Ewa Mazierska and Laura Rascaroli's Crossing New Europe (2006), where the genre of the road movie was examined as a starting point for capturing increased cinematic mobility in Europe. An edited volume by Daniela Berghahn and Claudia Sternberg, European Cinema in Motion (2010), discusses diasporic filmmakers and the portrayals of migration journeys, and also offers comparative studies of national film industries. More recently, European Cinema after the Wall (2014), a volume edited by Leen Engelen and Kris Van Heuckelom, takes this perspective further by focusing on East-West on-screen mobility and migration. These studies take issue with visible and invisible borders and barriers within Europe, as well as between Europe and other places, in order to deconstruct national, regional, and global identity formations.

Since the presence of Islam has always been relatively limited in Poland and Estonia (less than 1\% of the population in 2011, compared to $14 \%$ in Russia), Muslim characters have made rare appearances in these national cinemas. In socialist Poland, Muslims were featured only in relation to the distant past (and usually distant countries), as in Pan Wotodyjowski (Poland, 1969, Jerzy Hoffmann), a significant box-office success featuring the 1672 rebellion of the Lipka Tatars.
However, it is with Yosefa Loshitzky's Screening Strangers (2010) that the idea of "Fortress Europe" is most clearly demarcated; an idea that relates closely to Muslim identities, which are of specific interest here. According to Loshitzky (2010: 2), "European countries have tended to view migration as challenging and threatening to their territory, identity, and ways of imagining themselves and others. [---] Fortress Europe increasingly erects racial, ethnic, and religious boundaries." Given that "Fortress Europe" negates internal European migration as being at the heart of the European idea, it also negates a particular European Muslim identity.

Historically, Europe has always been made up of different religious identities, where Christianity has provided the majority of Europeans with an identity and Jewish and Muslim identities have been consigned to minorities. In this regard, representations of cinematic migration can be viewed as confrontations of minor versus major languages, as was highlighted by Gilles Deleuze and Félix Guattari in relation to Franz Kafka's writing. "Becoming-minor", they argued, was in itself an issue of questioning essential concepts of national identity (Deleuze, Guattari 1986 [1975]: 16-27). Deleuze and Guattari's use of a "minor language" versus dominating languages has sparked similar accounts within the rich field of "Deleuzian" film studies, where the notion of a "minor cinema", first coined in English by D. N. Rodowick (1997), has come to signify "attempts made by marginalised or minority groups to create a new sense of identity" (Martin-Jones 2006: 6). This concept has gained particular traction in Hamid Naficy's (2001) approach to exilic and diasporic cinema and Alison Butler's (2002) to women's cinema. In shifting the analytical material from a minor language to cinematic representations of migration, we can show how the processes of transnational migration, forced displacement, and diaspora building make the essential constellation of a nation unstable. To account for this instability, we find it useful to employ another Deleuzo-Guattarian term, 
deterritorialisation. Typically of their oeuvre, Deleuze and Guattari describe this concept and the processes related to it in different ways and in various contexts (e.g. [1972] 1983: 322; [1980] 1987: 88; [1975] 1986: 86; [1991] 1994: 68), but it has been briefly summarised "as a movement producing change" (Parr 2010: 69); "[t]he breaking up of order, boundaries and form to produce movement and growth, especially where this involves ... the disturbance of arbitrary or social rules employed in repression" (Sutton, Martin-Jones 2008: 142). Along these lines, we use it to describe the detachment of particular national signs, symbols, etc., from their established and fixed vertical hierarchy of meanings, identities, and contexts. In this sense, the term deterritorialisation embraces issues of minority, identity, and political power, and has the ability to break down cultural racism, which, as Loshitzky (2010: 4-5) rightly points out, is behind such dogmas as the "war on crime" or the "war on terror".

Our task is not to see the Muslim as the Other, but rather to view Muslim identities as internal and minor in relation to the (pan-)European identity. While this can create a differentiation between European Muslims and non-European Muslims, it is important to highlight a European identity that is encompassing different faiths. Kafka was European and his family had lived in Europe for generations, but Kafka's Jewishness and his German language made him "minor" in relation to the political power (cf. Deleuze, Guattari [1975] 1986: 16ff). Similarly, the Islamic belief of our characters makes them minor in relation to the established ideas about national affiliation, terrorism, and moral values. Our examples draw on the idea that Muslims in Europe should not be classified as estranged (Orgad 2012: 87-88), and even less as enemies, merely because they are Muslim. Our point is that the Muslim characters in the discussed films reveal, question, and destabilise the perceived, and often dominant, concept of Eastern European and European identity as Christian.

\section{MUSLIMS IN EASTERN EUROPEAN, SOVIET, AND RUSSIAN CINEMA: THE AFGHAN WAR AND THE WAR ON TERROR}

The Soviet Union had the largest population of Muslims in the socialist world, especially due to the autonomous republics of Chechnya and Dagestan where Muslims constituted the majority of the population, and Tatarstan and Bashkortostan, where they were a dominant minority. Thus, it is no wonder that Soviet cinema also dealt extensively with this issue. Dziga Vertov's film, Three Songs about Lenin (Три песни о Ленине, Russia, 1934), is a good example of how Soviet cinema rose to the task of narrating the new socialist space - with the unveiling of Muslim women as the crowning example of the ability of Soviet power to liberate the periphery of its patriarchal feudalism. In other words, more than his or her religion, it is the marginal position within the Empire that determines the role of the Muslim character in Soviet cinema.

For example, in Ivan Pyryev's The Swineherd and the Shepherd (aka They Met in Moscow/Cвинарка u nacmyx, Russia, 1941), the handsome (Muslim) shepherd from Dagestan travels to the All-Union Agricultural Exhibition, a celebration of the Soviet multicultural melting pot, where he meets and falls in love with a kolkhoz woman, who is also a stranger in Moscow. Leonid Gaidai's Kidnapping, Caucasian Style, or, The New Adventures of Shurik (Кавказская пленнича, или Новые приключения Шурика, Russia, 1967) continues the theme of the small nations of Soviet Union and the tradition of Russian literature cultivated by authors such as Alexander Pushkin and Mikhail Lermontov. In this film, Shurik, a famous Soviet comic character, travels to the Caucasus as an anthropologist to study the local customs. Not only does he save a local girl kidnapped for marriage, he also wins her heart in the end. Both films show the Chechen Muslim character as someone who can either spellbind or inflame his/her co-star. In these films, a melodrama and a romantic comedy respectively, the Muslim protagonists are somewhat peripheral while 
the centre is represented by the non-Muslim Soviet (wo)man. These are early narratives in which the imperial centre strives to project itself as the triumphant eradicator of backwardness in the land of the colonised natives. The postcolonial approach is perhaps best illustrated by Andrei Konchalovsky's First Teacher (Первый учитель, Russia, 1965) where the Soviet liberation project of the Islamic periphery is called into question (see Coxe 2003; on postcolonialism, see Mazierska et al. 2014), when a Red Army teacher comes in direct conflict with a stubborn settlement that refuses to see the light of education and breaks down the teacher's communist belief system. It is in this climate that the Soviet army enters Afghanistan in December 1979.

The Soviet war in Afghanistan, prompted by a conflict within the Afghan Communist Party, which took power in 1978, and a revolt in the Afghan military (Shaikh 2013), did not fulfil its main objective. The Soviets failed to conquer the rebel forces and take control of the country and eventually had to withdraw, experiencing the greatest Soviet humiliation in the twentieth century. Due to the sheer cost of keeping a large army on foreign soil, the war proved very costly, driving the Soviet Union into deep economic crisis, which was a major factor in the Soviet Union losing its position as a superpower, the subsequent dissolution of the Soviet bloc and the end of state socialism. The human cost was also high. It is estimated that during the ten years of the conflict over 14,000 Soviet soldiers died, over 50,000 were wounded, and over 400,000 fell ill from hepatitis, typhoid fever, and other diseases. The material and human losses on the Afghan side were even higher. During the ten years of the conflict, the Afghan economy and infrastructure crumbled and the country disintegrated, making it effectively impossible to govern; which to a large extent is still the case. It is estimated that 1.3 million Afghans, mainly civilians, died during this period and many were wounded and incapacitated. It is argued that the war gave rise to radical Islamism, in a large part due to the sup- port provided by the American government to the Mujahedeen in their fight against the Soviets (Shaikh 2013).

The Afghan war also affected the cinematic representations of Muslim characters in Soviet cinema. Once the Soviet armed forces entered Afghanistan in 1979, the images of conflict between Muslims and non-Muslims replaced that of collaboration. The Mujahedeen and Soviet soldiers are portrayed as warriors of faith and warriors of socialism, respectively. Furthermore, as the censorship eased in the 1980 s, the Mujahedeen are increasingly portrayed as noble savages with a pure, although irrational, will to sacrifice themselves, their family and, ultimately, the whole community in order to win their freedom. For the first time, the films showed that the Soviet soldiers were facing Islamic forces abroad that had anti-colonial reasons for refusing Soviet ideological domination. It is within this context that Soviet cinema, with great difficulty, approached the topic, for instance, several years into the war, in Juris Podnieks's documentary /s It Easy to Be Young? (Vai viegli būt jaunam, Latvia, 1986). This film outlines the ideological, social, national, and personal complexities of the situation where, instead of the coloniser and the colonised in the classical sense, two minorities are pitted against one another, doomed to lose-lose consequences. The Soviet TV miniseries All Costs Paid (за всё заплачено, Russia, 1988) by Aleksei Saltykov, one of the first Soviet feature films to show the war in Afghanistan, addressed the subject in a far more straightforward manner than Podnieks' film, with the main characters seeking to raise money for a monument in honour of their fallen comrades. With Vladimir Bortko's Afghan Breakdown (Афганский излом, Russia/Italy, 1990) and Timur Bekmabetov and Gennadi Gayumov's Peshavar Waltz (Пешаварский вальс, Russia, 1994) we see the topic developed into a full-blown action film with a trauma at its core on a par with Hollywood's representations of the Vietnam War. While the disintegration of the Soviet Union spread the trauma of the Afghan War 
unevenly among the former republics, other wars and traumas soon took the upper hand in Eastern European and Russian cinema, such as the violent breakup of Yugoslavia (1991-1992) and the wars in Chechnya (1994-1996 and 1999-2000). With these depictions, the image of the Muslim characters became grounded in post-imperial nationalism, i.e., Bosnian Muslim or Chechen Muslim, but this situation changed with the War on Terror.

After the events of 9/11, the "Muslim" characters in many cinemas around the world (including Eastern European cinema) turned into al-Qaeda fighters who have no particular national affiliation. Except for a few black widows, the prototypical fighter is a bearded male and an antagonist who resembles the Mujahedeen soldiers in spirit and determination. Furthermore, this Jihadist fighter stands in confrontation with European Christianity, which needs to be defeated (hence the formation of "fortress Europe", which in the post-communist era includes both Eastern and Western Europe, although retaining some critical internal lines of struggle). The converted Muslim, conceived within this context, begins to destabilise the homogenous concepts of belonging, whether they are religious or national constructs. In a very particular sense, the convert is "Othered" twice as s/ he is separated from a non-Muslim identity, as well as from other Muslims. This otherness resembles exilic and diasporic identities, which can open up narrative angles from their interstitial positions between the two homelands: narratives that are impossible from purely national and mainstream perspectives (Naficy 2001). This is what Deleuze and Guattari see as deterritorialisation: the possibility of other dimensions opened up by "becoming-minor" and it is in this sense that we will consider the Muslim convert in Eastern European and Russian cinema. The convert becomes the "impure one" that can morph himself, but also others, into new shapes. This transmutability is viewed as dangerous, because it can radically open eyes and ears to other narratives besides the established ones. According to Deleuze and Guattari, there are always three separate but intertwined movements involved in such a process: territory, deterritorialisation, and reterritorialisation. "Perhaps every territory presupposes a priori deterritorialisation, or everything happens at the same time", but to disentangle the knot, "we need to diagnose real types or personae" to whom these processes are assigned (Deleuze, Guattari [1991] 1994: 68; emphasis in the original). Examples that Deleuze and Guattari give are the merchant who deterritorialises products from the territory into commodities that are reterritorialised on the market; the exiled who are deterritorialised from their homeland (territory) to a host-land (reterritorialisation); or the capitalist who deterriorialises capital/ property from its connection with the land and reterritorialises it as a means of production, and "labour [which] becomes "abstract" labour, reterritorialised in wages" (Deleuze, Guattari [1991] 1994: 68). We propose that the convert is such a "conceptual persona" that sheds light on the inherent instability of ethnic, national, and religious identities. The convert challenges such identities, because of her/his deterritorialisation from one religion and reterritorialisation into another.

The three films highlighted in this analysis present the convert to Islam as the trigger of the narrative. In each film the main character travels either voluntarily, to answer a religious calling, or by force. In Letters to Angel and A Muslim, his destination is "home", a place where he once lived; in Essential Killing, by contrast, the original home of the protagonist remains unknown, or at least ambiguous, to the viewer, even if his own projections of a true "home" are firmly established in a Middle Eastern context. Our point is that these deterritorialised Muslims are creating friction in the homogenous image of self in terms of national constellations, religious beliefs, and communal belonging. Are they still themselves? This is the question these characters are asked when returning to their (former) homes. These Western converts to Islam all have different trajectories and objectives, but the main reason for the filmmakers to evoke their 
deterritorialising exploits is the effect they have on their surroundings. Thus the homecoming in these narratives is far from the style of the migrant homecomings as represented in trafficking stories (Brown et al. 2010) or of the positive narratives of Westerners returning to Eastern Europe in search of their roots (see Gott 2014: 6-14). Neither are the Muslim converts "the other within" in a traditional, historical sense, like the Jews and Roma in Europe (Loshitzky 2010: 4).

Before we move to the analysis, we need to briefly describe the production and distribution of the films, because such factors inevitably affect the ideology of the films, including the ways the Muslim characters are represented, which are of paramount importance to us.

\section{DIRECTOR-AUTEURS AND CO-PRODUCTIONS: IMPACT AND FUNDING}

When accounting for the production and reception of films, we are often faced with divergent opinions, concerning issues such as whether a film is still a national product when co-produced by two companies in two different countries and whether festival screenings function as evidence of significant impact on audiences. A Moslem is most clearly a national product; with backing from the Russian state at a time when very few grants were given to film production. A Moslem received $\$ 115,000$ from Roskomkino, which was the state agency for film funding, while the director's own studio contributed less than $20 \%$ of that amount (Beumers 1999: 880), which created "heated discussions" about state-financed filmmaking at the International Film Festival in Sochi the following year (Johnson 1997: 281-282). However, it had a rather limited domestic audience, partly due to the fact that the distribution system in Russia had not recuperated after the collapse of the Soviet Union. A Moslem was screened at the Toronto Film Festival and had a general release in France where over 8,000 viewers saw the film. ${ }^{2}$

2 All attendance figures are taken from the Lumiere database on admissions of films released in Europe: http://lumiere.obs.coe.int/web/search/.
Essential Killing can be seen as a transnational film, since it was made by film companies from five different countries - Poland, Norway, Ireland, Hungary, and France. This ensured some distribution, although the film was in danger of being categorised as Euro-pudding, i.e. a film that is driven by European integration policies rather than the depth of the narrative (Jäckel 1997). Moreover, it screened at all the major festivals - Venice ${ }^{3}$ and Toronto, for example - and was distributed in many European countries, but failed to get a general release in the United States, which somewhat diminished its political potential. It also did rather well among domestic viewers with nearly 75,000 tickets sold. Of the three films discussed here, Essential Killing sold the most tickets in Europe - nearly 150,000 with about 45,000 tickets sold in France.

Letters to Angel sold nearly 5,000 tickets in Estonia and fewer than 100 cinemagoers saw the film in Latvia. It was only cofinanced by Finland, but not co-produced, i.e., Keedus and his Estonian producer F-Seitse retained total control over the content. The issue of artistic control over the production leads us to the concept of the auteur as the ultimate author of a film. Keedus and Skolimowski can be perceived as auteurs, as the films they directed were based on their scripts (in case of Letters to Angel co-written with Madis Kõiv), and they exerted significant control over their production. Skolimowski's artistic freedom was largely due to generous support from the Polish Film Institute, in recognition of the fact that along with Andrzej Wajda, he is the most important Polish director currently working in Poland. The fact that after the fall of the Berlin Wall he decided to leave the United States, where he had lived and worked for many years, and resume his career in Poland, affords him extra prestige in his native country. Vladimir Khotinenko's

Essential Killing opened at the 67th edition of the Venice International Film Festival in 2010 where it won two major awards, the Special Jury Prize and the Coppa Volpi for the Best Actor (Vincent Gallo as Mohammed), an unprecedented exception to the rules of the festival. 
relationship with authorship remains different from Skolimowski's. Khotinenko emerged during the post-communist era as one of the filmmakers building their own studios in Russia and has continued making goszakaz (госзаказ) films - films made on order from the government (Norris 2012: 259-262). With strongly nationalistic productions about mostly historical events, Khotinenko has become synonymous with anti-auteurist and conformist filmmaking, enjoying the full backing of the Russian political authorities. This is in striking contrast with Sulev Keedus, whose auteurist practices bring a particular style to his works, thereby branding his oeuvre similarly to other European directors, for example, Lars von Trier, the Dardenne brothers, and Pedro Almodóvar. Since he is working in the cinema of small country, the budgets at Keedus's disposal are far smaller than Skolimowski's or Khotinenko's, but he has used this to his advantage by implementing stylistic and authorial control over his productions. In addition to directing, Keedus typically contributes extensively to the scripts of his films (alongside Madis Kõiv, his usual screenwriting partner). We will now turn to the individual case studies structured in chronological order.

\section{A MOSLEM: A (MUSLIM)}

ALIEN IN AN (ORTHODOX) HOME

A Moslem can be seen as a precursor to Putin-style blockbuster cinema. The film deals with the trauma of war, but in a far subtler way than later post-Soviet Russian films, such as Janick Faiziev's The Turkish Gambit (Турецкий гамбит, Russia/Bulgaria, 2005) and Khotinenko's own epic history drama 1612 (Russia, 2007). The deterritorialising factor in A Moslem is manifested by the fact that the national context is questioned, which allows for other narratives to emerge. It is no wonder that the converted Muslim causes problems in a climate of post-imperial nationalism, because, in such a context, the spectre of old imperial constellations persists, while new lines are being drawn in the sand between us and them, self and the Other. In Russian cinema, the trauma of the Afghan War lingers on but only in the background. For example, Fedor Bondarchuk's The 9th Company (9 poma, Finland/Russia/Ukraine, 2005), partly set in Afghanistan, reveals little about the conflict itself, resorting instead to a nostalgic celebration of the Soviet system. Bondarchuk's film includes a Chechen soldier in the fight against the religious Islamists, and as mentioned above, underlines the values of the periphery of the Empire as more important than the religious values (van Gorp 2012: 20). However, A Moslem is different in this regard.

In the mid 1990s, everything was still up in the air and Russia was in a sort of transitional flux, where any national discourse could still achieve hegemony over the others. In other words, a particular narrative within which the national question could be addressed was yet to be established. A reformed monarchy, secular democracy, post-Soviet imperialism, Russian isolationism, national socialism, ethnic multiculturalism, centralised federacy - all these were part of the mix in the early to mid-1990s. Perceived as members of the new post-Soviet intelligentsia, Khotinenko and his peers had a clearly anti-modernist agenda (Beumers 1999: 892) and were highly critical of Yeltsin's politics and the decline in moral values. Also called quasiintellectuals (raznochinets, разночинеч; Дондурей 2000), these filmmakers, from Nikita Mikhalkov to Aleksei Balabanov, wanted to teach audiences to love the motherland, which they believed had been corrupted by Western-like behaviour and values. Cinema, in their hands, could, and should, instil moral values in the audiences and effectively provide guidance during the treacherous post-communist transition period (Beumers 1999: 892). A Moslem is a good example of this kind of filmmaking.

Khoteninko's film appeared in a period before terrorism in Russia and elsewhere was being attributed to Islamists and Jihadists, that is, before the 1999 bombings of the apartment blocks in several Russian cities, killing nearly 300 people, and the 2002 Nord-Ost siege in Moscow, which 
resulted in 170 hostages and hostage takers being killed. With both these incidents, the adjective "Muslim" was attached to the word terrorism in connection with the event, which was, in particular, attributed to Chechen separatists. However, these attacks are predominantly associated with the Second War in Chechnya (19992009), while A Moslem deals with the First Chechen War (1994-1996), which had different connotations. The First Chechen War was deeply unpopular in Russia as demonstrated by the fact that mothers of soldiers travelled to the region to fight for the release of their ill-prepared sons from the army or, worse, from Chechen captivity. The Chechen combatants were not depicted as barbaric and their claim to independence was regarded as legitimate, as seen in the film Prisoner of the Mountains (Кавказский пленник, Russia/Kazakhstan, 1996) by Sergei Bodrov. Similarly, A Moslem refuses to demonise the Islamic other, and instead supports the continuation of the Soviet Empire, where all nations are equal, even if best served by Russian patronage (Graffy 1996: 24). Despite its straightforward imagery of a Muslim at home, it is also the beginning of the end of Russia's overbearing attitude toward the nationalist separatists. It is not long after that we see Chechen nationals in Russian cinema being targeted as alien foreigners that do not belong in Russia (Hashamova 2007: 47-48).

In the opening image of the film, we first hear and then see a singing priest walking up a lush green hill. The birds are singing in the sky. As he walks toward the camera, the camera pans to reveal rural Russia drenched in sunshine, with rivers, embankments, and thick forests as far as the eye can see. The song of the priest is accentuated by an echo that makes the landscape feel like an eternal cathedral. The holy place, or sacred village, will be evoked later in the film through allusions to the legend of Kitezh, according to which the holy city was submerged into a lake since it refused to surrender to the Mongolian forces at its gates. Vida T. Johnson has noticed similar extreme long shots of time- less mythical landscapes in many other films of the era, arguing that this "compensates for the absence or death" of an identifiable hero (Johnson 1997: 283-284).

The fact that the film opens with a priest tells us that, despite the title, the film is actually not about Islam or particular Islamic values. Once we have left the priest and the film credits, we are introduced to Sonya (Nina Usatova) sitting in her living room, working at her spinning wheel and watching TV - again emphasising that the focus is on traditional Russian values. From the TV, we hear an announcement that a Russian soldier has been located in Afghanistan and will be returning home after all these years in "captivity". Nikolai (Kolya, Evgenii Mironov), Sonya's son, is revealed to be the soldier. Watching this news, Sonya faints, breaking her spinning wheel. The broken spinning wheel will emerge as the film's subplot, as we keep seeing Kolya trying to fix it by cutting and carving a new leg for it. Kolya is presented as a mending force - a repairman who has returned home to fix the country. ${ }^{4}$ Based on Deleuze and Guattari's sense of deterritorialisation, we can argue that Kolya's constant repair efforts - efforts of reterritorialisation - force the community to look for their own territory comprised of religious and national signs and symbols.

Upon his arrival, Kolya is told that his father hanged himself and that his brother, Fedya (Aleksandr Baluev), who cut down his father's body, has been drinking heavily ever since. Moreover, as a converted Muslim, adopting Islamic values and dress, Kolya greatest physical and psychological struggle is with Fedya. Devoted to his faith, refusing to consume alcohol and silently devoted to his work, Kolya is everything Fedya is not. Even though Fedya does not practice religion and is asked by the priest to attend church services, he tries to force Kolya to kiss the family icon. Somehow, Fedya is provoked by Kolya's purity to change his

4 The repairman, or the fixer, was a common character in the films of the mid-1990s, e.g. in Prisoner of the Mountains by Sergei Bodrov and in Brother (5pam, Russia, 1997) by Aleksei Balabanov. 


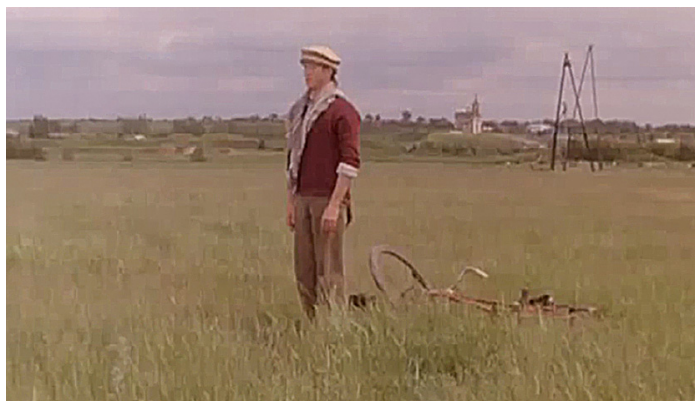

1

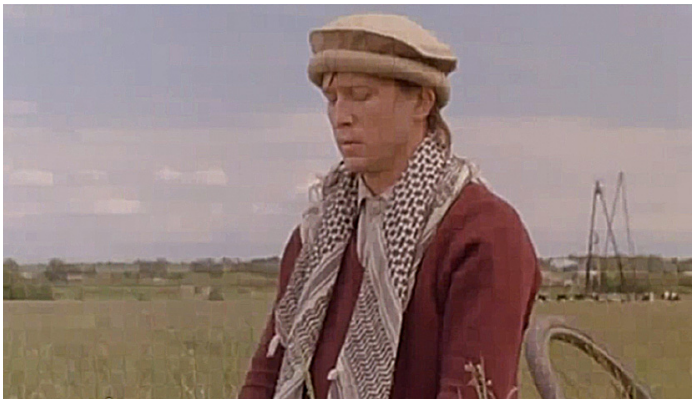

2

FIGURE 1-2. A Moslem (Мусульманин) by Vladimir Khotinenko (Russia, 1996). 
ways and to reterritorialise to the religious icon. The bottom line is that Kolya is not the unsettled one - his mother Sonya, Fedya, and the rest of the villagers are the ones who are deterritorialised by Kolya. Kolya's silence, his non-condemning demeanour, and his forgiving character disturb the equilibrium of the post-communist society. Kolya disrupts the road taken by Russian towards Western-style secularism and decadence with his religious belief in only one God. By becoming-minor, he opens up the possibility that everybody can change. Thus, suddenly everybody can avoid the slippery slope into the hedonism of late capitalism. In this sense, Kolya's presence can be compared to that of the characters in Essential Killing and Letters to Angel. Between them, these converts might have a common reason for embracing Islam, but the raison d'être of each film diverges. In A Moslem, Khotinenko uses the deterritorialisation effect of the Muslim convert to further his anti-modernist agenda.

In A Moslem, the idea of salvation is located in religious belief - Kolya is a Christ-like figure. For example, when an old army comrade (who thinks Kolya betrayed his company during the war) shoots him in the stomach, Kolya, with his wound and red blood on his white shirt, resembles Christ (Swaffar 2000: 109). Kolya's sacrificial death is portrayed with the same biblical iconography. This suggests that Kolya's conversion is shorthand for purity and innocence, rather than Islamic literacy or Russian Muslimhood. In this sense, Kolya resembles the pure, childlike protagonist of the Dostoyevskian mode, uncontaminated by vices, seen most clearly in Prince Myshkin and Alyosha Karamazov. These heroes' beliefs unsettle the balance of the narrative and their ultimate destruction is part of the sinful liturgy of Christianity. Both Myshkin and Alyosha leave at the end of the novels and, in the same vein, Kolya cannot be present in the final images of the narrative. This denial of Kolya's presence runs contrary to previous interpretations, which juxtapose the image of Kolya-the-Muslim-Other praying in the fields against the Orthodox Church in the distant background (Gillespie 2003: 141142; Lawton 2004: 183-184; Beumers 2009: 237). We argue against this interpretation, since Kolya's religious vows of chastity, not his invisible conversion to Islam, are at the centre of the film's narrative. It is salvation through religious belief that lies at the heart of the film, as opposed to adherence to a particular religion.

Kolya's actions when he saves his brother from hanging himself as his father did are expressive in this sense. Kolya, the saviour, tells the villagers that it is time to "stop these suicides". It is a sin to commit suicide, says Kolya, but "it is easy to sin" - as easy as to drink water. Kolya's point is that God loves them nonetheless - "he loves you even if you do not love him". Hence, belief is what matters. Jolyon Mitchell examines the entire history of Russian and Soviet cinema for signs of religion and peace and, not surprisingly, it is "Orthodox priests and monks" who come out on top "as guides or models for those searching for peace" (Mitchell 2008: 151). However, according to Mitchell, A Moslem is part of a post-communist embrace of religious faith (Mitchell 2008: 149). So despite the fact that Kolya is not a monk or a priest his faith is meant to territorialise, in the Lacanian sense, the corrupt post-communist subjects into once again embracing Orthodoxy as their saviour. In the eyes of the filmmakers, the post-communist moral degradation needs to be reversed and Kolya's homecoming opens the way for Orthodox Christianity to regain its foothold in Russian society. Thus A Moslem is ultimately framed within local Russian objectives and concerns.

\section{ESSENTIAL KILLING: TERRORISM DETERRITORIALISED}

While Huntington's "clash of civilisations" thesis, according to which cultural and religious identities are seen as the primary sources of conflict in the post-communist era (Huntington 1996), became firmly established as the dominant discourse in the aftermath of $9 / 11$, and a shadow of the "War on Terror" was cast onto practically all 
Muslims, Jerzy Skolimowski's Essential Killing performs a set of minimalist and subtle, yet compelling, subversions in order to question such battlefronts and arguablly "natural" alliances. Reduced to the "essential" in narrative and visual form, the film is based on an idea that came to the director when he nearly crashed his car on a wintry road two kilometres from the Szczytno-Szymany airport in north-eastern Poland, close to his house in Masuria (Franklin 2010). He knew of the (later confirmed) rumours that the airport was used to service a nearby CIA "black site" where terrorist suspects, including Khalid Sheikh Mohammed, the "principal architect of the 9/11 attacks" (Kean et al.s.a.: 145), were covertly interrogated and tortured. After the incident, Skolimowski started to wonder what would happen if one of these terrorist suspects escaped, barefoot and in shackles, wearing a prisoner's uniform (Franklin 2010). Would he return "to the state of a wild animal, who has to kill in order to survive" (Dawson 2011)?

The majority of Polish critics read the film "universally" rather than "politically", encouraged by Skolimowski himself, who argued that "[t]he political aspects of the situation didn't interest me: to me politics is a dirty game and I don't want to voice my opinions" (Dawson 2011). ${ }^{5}$ By contrast, we argue that since the film clearly problematises the dominant discourse on Muslims as mad and violent terrorists and the Western allies as a united front of heroic warriors against "terror(ism)", its political potential cannot be disregarded. In order to illuminate the film's social and political polemics, we can again turn to the Deluzo-Guattarian concept of deterritorialisation. Drawing on Lacan's psychoanalytic idea of territoriali-

Such statements are almost obligatory in the Polish context. While in the Russian case, Khotinenko is happy to be associated with the political powers, it is more difficult for a Polish filmmaker to declare his/her political allegiances. Moreover, a director admitting to being interested in politics or supporting any political programme would simply alienate audiences. Finally, Skolimowski denies such a claim since it can be seen as pre-empting the accusation of supporting a terrorist - which in fact was an accusation directed at this film by some critics. sation, which "programs desire to valorize certain organs and objects at the expense of others", Deleuzo-Guattarian deterritorialisation "designates ... the process of freeing desire from established organs and objects" (Holland 1999: 19). It is important to note that Deleuze and Guattari's refusal to fix the meaning of the concepts they use can be compared to Skolimowski's predilection for vagueness, or "poetic" expression. In Essential Killing, he mobilises a number of discourses and identities, without reterritorialising them, i.e. without necessarily providing definitive judgments or unequivocal standpoints of his own, and often rejecting binary frames of reference. The only exception seems to be his obvious distaste towards the American "superpower", represented by almost stereotypically idiotic, pot-smoking soldiers, cracking offensive, patronising jokes at the expense of the miseries of the "Third World", and their disturbingly cruel superiors who imagine themselves as the ultimate rulers of the world. In the opening sequence of Essential Killing, the protagonist, Mohammed (Vincent Gallo), is captured by the US soldiers and subjected to unsettlingly violent and humiliating interrogation. (Figure 3) Importantly, we never learn if he is guilty of any intentional assault beyond self-defence (true, he does blow up a couple of American Gls after being cornered on a barren, labyrinthine battlefield). On the contrary, his heavy breathing signals a rather genuine sense of terror, untypical of a cold-blooded killer. At the same time, the film does not explain how and why he ended up in this combat zone, which appears to be in a remote desert, signalling that he is most likely a mercenary, rather than a civilian bystander. Even so, the audience is still unaware of the circumstances of his choices. Furthermore, his identity is also ambiguous - although he has long hair, a beard, and wears Pashtun dress, the fact that the American actor Vincent Gallo was cast in Mohammed's role has led many commentators to speculate that he might be a Muslim convert of American origin. The confusion is intensified by the character never uttering a word - at first, this is 
motivated by his (temporary) deafness caused by the explosion of a missile shot at him by the American soldiers; later, escaping from his pursuers on a wintry landscape, he is forced to remain silent in order to avoid being recaptured. His voice deprivation can be interpreted "as a metaphor of discursive cleansing of all the voices of those who disagree with American policy" (Mazierska 2014: 114). All in all, the dislocation of Mohammed's identity and status betrays Skolimowski's desire to evade, deterritorialise the dominant discourse on, and understanding of, both Muslim people, and especially Muslim fighters, as presenting a clear and present danger to Western civilization and its notion of "humanity". Despite Mohammed's acts of aggression, which are, as noted, shown as motivated by a primal survival instinct (Ladegaard 2013: 182), he comes across as a much more sympathetic character than the American "warriors on terror" whose massive, systematic, and mechanised violence is portrayed as grossly disproportionate.

Once the narrative moves from the initial arid Middle Eastern setting to the frosty, apparently Polish, woodland where the crash of the transport vehicle provides Mohammed with a chance to flee, Skolimowski activates a series of Christian symbols, similarly to Khotinenko in A Moslem, which, in combination with Mohammed's Muslim affiliations and Skolimowski's own known distaste for institutionalised religion (see Mazierska 2010:37), produce a perplexing constellation of images and meanings. On his excruciating "journey to nowhere" (Nawój 2014) through the wintry forest, Mohammed spends a night in a manger filled with hay, eats raw fish (in addition to ants, tree bark, and hallucinogenic wild berries), sucks the breast milk of a new mother (Figure 4), rides on a white horse, and is fatally wounded in the chest. The iconography of these Biblical symbols refers unmistakably to Christ - the manger paralleling Jesus's Holy Cradle in Bethlehem; the fish being a popular symbol of Christ in early Christianity ${ }^{6}$; the shots of Mohammed drinking breast milk bringing to mind images of the Nursing Madonna (Madonna Lactans) breastfeeding the infant Jesus - a symbol of Coptic and Palestinian origin, and later especially favoured in the Eastern Orthodox Church (Tradigo 2006: 183); the white horse invoking the Four Horsemen of the Apocalypse in Revelation 6:1-8, the first of whom rides on a white horse and is usually interpreted as the Messianic King Jesus Christ; finally, Mohammed's fatal chest wound resembling the last of the "Five Holy Wounds", in the side of Jesus' chest. Yet by attaching these symbols to a character identified as Muslim, Skolimowski deterritorialises them from their established frame of reference. Hence, despite the obvious similarities, it is difficult to read Mohammed as a martyr whose death could redeem the sins of (Western? Muslim?) humankind (and perhaps reconcile the "clashing civilisations"). Rather, as observed earlier, he can be described as a homo sacer (Mazierska 2014: 115), an enigmatic and contradictory figure of archaic Roman law, a convicted criminal whose specificity is constituted by "the unpunishability of his killing and the ban on his sacrifice" (Agamben 1998: 48). According to Giorgio Agamben, an inmate of a Nazi concentration camp that is exterminated as "a louse" is a "flagrant case" of this "bare life", standing simultaneously both inside and outside the law (Agamben 1998: 68). Mohammad's plight, and the status of Muslims (especially, but not only, the fundamentalists) in the West, is indeed not very far removed from the Nazi discourse on Jews. But first and foremost, both Agamben and Skolimowski seem to suggest that "we are all virtually homines sacri", potential victims of political manipulations, irrespective of our particular religious and cultural backgrounds.

Another aspect of deterritorialisation

in Essential Killing relates to the interwoven

6

The Greek word for "fish" (ix $\theta$ ús, ichthys) is formed

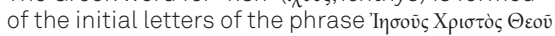
Yiòs $\Sigma \omega \tau$ inj (lësous Christos Theou Hyios Sōtēr), meaning, "Jesus Christ, Son of God, Saviour". 

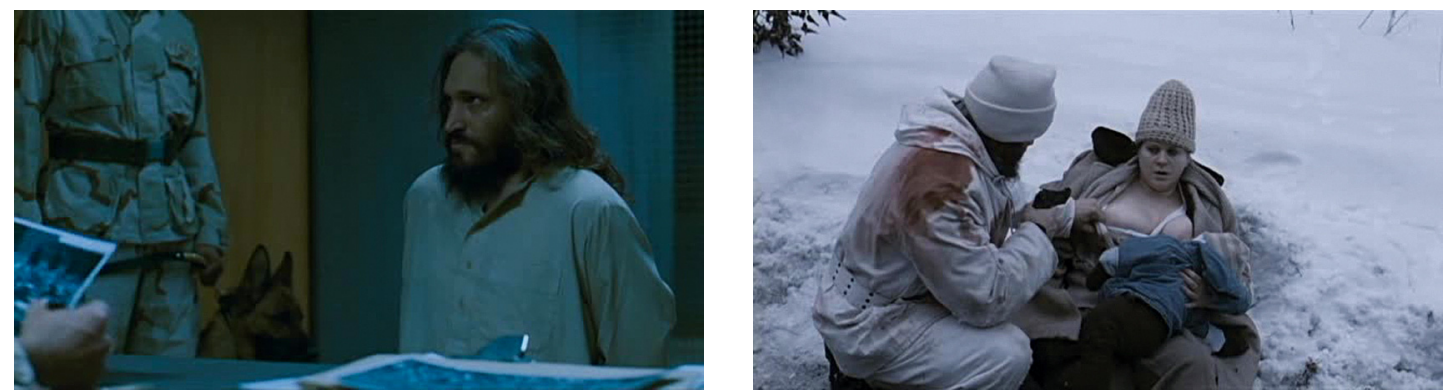

3

4
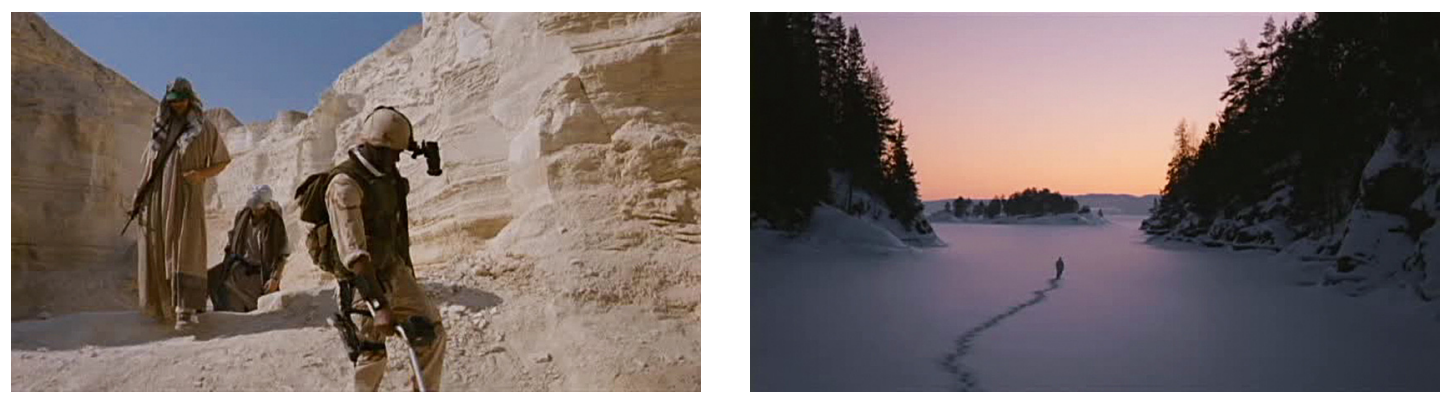

5

6

FIGURE 3-6. Essential Killing by Jerzy Skolimowski (Poland/Norway/Ireland/Hungary/France, 2010). 
discourses of colonialism and Orientalism. On the one hand, there appears to be polarisation between the global "South" and "North", the first represented by the parched Arabic battlefront (Figure 5), as well as by Mohammed's dream sequences featuring radiant visions of a peaceful Oriental existence. On the other hand, although at first glance, the global "North" appears to be at the other extreme, glistening with beautiful but ultimately deadly frost (Figure 6), these two apparently opposing environments actually share a number of similarities. Both come across as magnificent and "virgin", yet also barren and hostile, not unlike the landscapes in Westerns (Ladegaard 2013: 183), but equally exoticised. Both are portrayed as zones of war where "normal" laws are suspended, yet both contain enclaves of compassion and homeliness, whether real (the Polish woman who takes care of Mohammed) or imaginary (the woman in a blue burka in his dreams). But most importantly, both territories are ultimately governed, or colonised, by the American "counter-terrorist Empire", not unlike in Letters to Angel, which we will analyse next. American hightech weaponry and sophisticated military strategies (even if unsuccessful in capturing Mohammed), their "rationalised", "urbane" violence is contrasted with Mohammed's beastly, instinctual behaviour, as well as with the Polish rural environs and traditional, nature-conscious existence (cf. Said 1978: 300; Loomba 1997: 47). In other words, in relation to the Americans, both the soldiers shown in the film and the American domination in general, Skolimowski's narrative "Orientalises" both the "south" and the "north", thus deterritorialising the official Eastern European alliance with the United States and demonstrating that this alliance is far from balanced.

\section{LETTERS TO ANGEL: A RETURN OF A "TRUE MAN" TO HIS OLD HOMELAND}

Similar aspirations can be detected in the intentions of Sulev Keedus, the author of Letters to Angel who draws intriguing parallels between two peripheries - the newly independent capitalist Estonia and Afghanistan, scarred by never-ending conflicts.

The film takes issue with the Soviet invasion of Afghanistan and its aftermath. The conflict with Afghanistan has a particularly strong influence on the history of the Soviet Baltic Republics, because a disproportionally large number of the Soviet soldiers fighting in Afghanistan came from this region. This was a reflection of an unofficial Soviet policy of favouring the Russian population over the inhabitants of other republics, in this case ensuring that the Russians had a better chance of being spared the war experience than, for example, Latvians or Estonians. Such a policy confirms a rule, identified by Michael Hardt and Antonio Negri, that in contemporary wars the soldiers who run the greatest risk on the front lines are not the US troops, but the "allied forces" (2006: 46-47). Hardt and Negri base this idea on an analysis of the wars conducted by the United States, but the behaviour of the Soviet Union during its wars also confirms this point. By and large, the behaviour of the two superpowers point to their imperial attitudes towards both their allies and their enemies.

Prior to Letters to Angel, the significance of the Afghan war for the history and self-image of the Baltic region was proven by the production of the aforementioned Is It Easy to Be Young?. Another film which takes issue with the Afghan war is Baltic Love Stories (Balti armastuslood, Finland/ Estonia, 1992) by Peeter Urbla. In one part of this tripartite film, which is set in Latvia, we encounter Sergei (Sergei Varchuk), a Russian man who is prevented from marrying his Latvian fiancée Regina (Liana Upeniece) by his two Russian friends who fought with him and saved his life in the Afghan war. The Afghan war is seen by them as a kind of litmus test of one's Russianness, and by the same token, as distancing them from their former "brothers", the inhabitants of other Soviet republics, now seen as Russia's arch-enemies. It is worth adding that this Russianness is presented as aggressively masculine, while Latvianness (and the Baltic region generally) is 
viewed as feminine. Needless to say, Urbla, being Estonian, criticises such a construction of the Russian identity, seeing it as damaging for both Russians and their Baltic brothers. Taking a cue from this film, we might expect that Letters to Angel would likewise criticise Russian/Soviet nationalism and macho masculinity.

Letters to Angel broaches a subject that would have been off-limits for filmmakers during Soviet times: desertion by Soviet soldiers and their joining the enemy - the Afghan Muslim forces or Mujahedeen. According to the Islamist.com website, there are a significant number of (ex-) Soviet men with Muslim names in Afghanistan (Coghlan 2013). These "deterritorialised" men, both in the geographic and symbolic sense, appear to be well-integrated into the local communities, often married to local women. Even though Afghanistan is one of the poorest and most dangerous countries in the world, and the majority of the countries reborn from the ashes of the Soviet Union are democracies with consumer culture and some degree of the welfare system, they are unwilling to return to them.

Letters to Angel attempts to explain, or rather imagine, why a Soviet Estonian soldier would desert his army and decide to stay in Afghanistan and how he perceives his homeland more than twenty years after the end of the war. The film's protagonist, Jeremia Juunas Kirotaja (Tõnu Oja), visits Estonia to attend his father's funeral. It is also possible that he is looking for his daughter, who was very young when he left for the war, or because he has recently lost contact with his Afghan stepdaughter. The motifs of absent fathers and fathers or sons trying to make contact with their children or parents resonate in two of the discussed films. It can be linked to a crisis of masculinity and the need to overcome it by returning to one's country.

All these reasons are alluded to, rather than spelt out clearly, perhaps indicating the fact, mentioned by Kirotaja, that our actions are never entirely rational. Kirotaja's return, however, is used by the director less to discuss the Soviet war in Afghanistan than to draw comparisons between Afghanistan and Estonia, as seen through the veteran's eyes. It is important to note that his eyes are injured a result of the bomb blasts during combat. (Figure 7) It could be argued that he sees everything more sharply because of his over-sensitive eyes. In particular, what he sees comes across as strange, enlarged, and grotesque: apartment interiors look like churches, offices like abandoned military quarters. Moreover, Kirotaja sees the world as being largely empty of people. This might be a consequence of his moving in such sparsely populated places (Estonia has low population density) or him seeing fewer objects more intensely. Here, one can draw a comparison with the silence of Skolimowski's protagonist. In both cases the characters' impaired senses both limit their interaction with the environment, but also, in a way, make them more perceptive than the people around them. This renders the protagonists as strangers, but also important presences, in the places they appear, almost prophets.

By and large, Letters to Angel is poignantly anti-realist. It consists of a series of loose episodes rather than a linear narrative. Multiple viewings are needed to reconstruct the plot. Frequently a clash between the behaviour of the characters and their surroundings occurs, for example, we see the naked women covered in clay near a lake, or the female cellist performing on the grass near a beach in a scene reminiscent of René Magritte's paintings or Jerzy Skolimowski's films from the 1960s, which were inspired by surrealist art. Even the washedout colours are not realistic, but suggest a deeply subjective vision of someone who is disillusioned, for whom the world has lost its colour. (Figure 8) This style is typical of Keedus, who has used it before in Georgica (Estonia, 1998) and Somnambulance (Somnambuul, Estonia, 2003), but in the context of representing Muslims, it might signify the director's refusal to succumb to the allegedly "realistic" representations of Muslims offered in American mainstream media, pointing to the fact that each image of a 
Muslim is ultimately subjective, depending on the place and the person who is looking at it. By the same token, it can be seen as an attempt to provide the Muslim character with the "power of the gaze".

Kirotaja says that he decided to stay in Afghanistan and become a Muslim when he saved the life of a little girl, Safija, during an attack by Russian troops on the Afghan enemy. Subsequently she saved his life in what was more of a series of coincidences and impromptu decisions than any conscious and premeditated actions resulting from a rejection of Soviet politics. The accidental nature of these events make him believe that it was Allah's will that he and the little girl were saved. Following his capture by the Mujahedeen troops, he converts to Islam and becomes devout, as demonstrated by his Muslim dress, his refusal to drink alcohol, and his prayers.

In many ways, the Estonia to which the veteran returns reminds him of Afghanistan, and in other ways, provides a poignant contrast with his adopted country. The common features are that they are both sparsely populated, almost wild, countries with huge stretches of uninhabited land (or, at least, this is how Kirotaja sees it). However, we learn early in the film, that this seemingly empty land is an object of land speculation, with foreigners wanting to buy it for investment. One of the female characters, Senta (Ragne Pekarev), living in Kirotaja's former hometown, marries a Dane, Lars (Kaido Kelder), who is eager to invest in real estate there. (Figure 9) Again, this renders Estonia similar to Afghanistan, whose recent history can be seen as a series of occupation and various forms of land grabbing, first by the communist Soviet Russia, then by the Western powers, most importantly the United States. Wherever Kirotaja turns, he witnesses signs of the preparation for war - the (in)famous War on Terror, conducted by the United States with the assistance of its provincial allies, such as some ex-Soviet republics and satellite states, as shown in Skolimowski's film. For example, on his way to his hometown, the traffic has been stopped and Kirotaja sees burnt cars and people being carried on stretchers. When he asks what is going on, he is told that this is a special military exercise. The building that houses the archives of property deeds and other documents about land rights in Estonia is located in the vicinity of an antiterrorist training base. The fact that these two institutions are so close to each other is symbolic, as it suggests that the War on Terror could affect property rights in Estonia. Although nobody mentions the United States, we can conjecture that this antiterrorist activity serves the US rather than Estonia. In Kirotaja's eyes, which can also be seen as the eyes of Keedus and the scriptwriter Madis Kõiv, the Afghan-Soviet War and the Afghan-American War constitute a continuum. This fact is also underscored by the stories about various people told or alluded to in the film. One is the story of Kirotaja's foster daughter, Safija, who as a child ran away from the Soviet aggressors who had killed her parents and siblings, only to turn some twenty years later into a terrorist, a "suicide bomber", attacking American targets, as Kirotaja learns from watching television in Estonia. Another is his absent male relative, who has left his pregnant wife in rural Estonia, not unlike Kirotaja who left his own wife many years ago to fight in a war. It is worth mentioning that Keedus's representation of the war as a never-ending conflict, in which the poor and dispossessed have to pay over and over again for the greed and power hunger of the mighty, coincides with Hardt and Negri's diagnosis of the contemporary stage of capitalism, as marked by continuous war and with David Harvey's claim that war is a means to speed up capitalist accumulation (Harvey 2006: 445). Such an opinion, as we already indicated, also pertains to Essential Killing.

Most of the people the war veteran encounters are women. The few remaining men are seriously debilitated. One group are the inmates of a mental asylum, who amuse themselves all day by hitting a ball with a racket. Another man, Elvis (Rain Simmul), a chemist, composer, video artist, and husband of a cellist named Merily (Mirtel Pohla), 

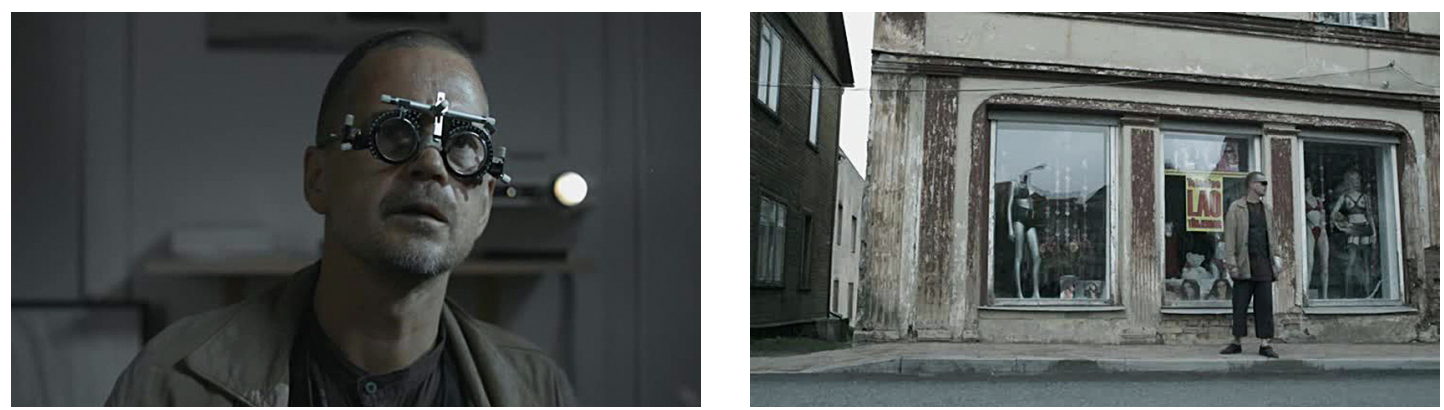

7

8
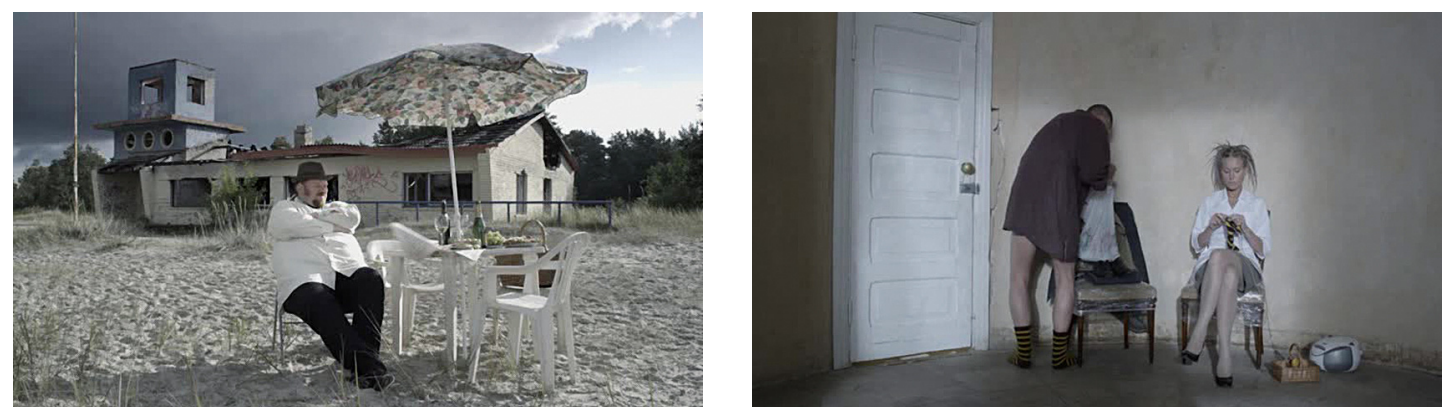

10

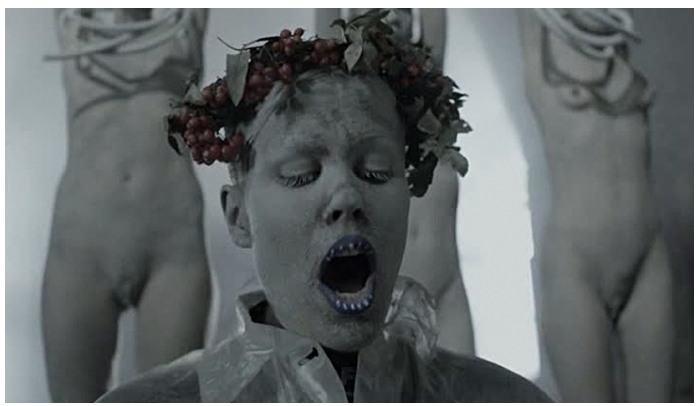

11

FIGURE 7-11. Letters to Angel (Kirjad inglile) by Sulev Keedus (Estonia, 2011). 
is claimed by her to have homicidal tendencies towards her and when approached by Kirotaja, he behaves as if he were under the influence of drugs or suffering from a stroke. These men have completely lost contact with the real world. The women who have taken their place superficially enjoy the privileges of emancipation. They are loud and not afraid to express their erotic desires and show their bodies. By contrast, they shun the traditional paths taken by women. One of them describes the female expectations related to a new relationship: "the honeymoon, the romance, and the sex, but not getting married". However, ultimately the lack of men does not empower the women, but makes them hungry for male company, and even predatory in their relationships with men, as well as neurotic, disorientated, and unhappy. By and large, the country visited by Kirotaja is permeated by emotional coldness and verging on madness.

For the numerous single women, Kirotaja appears to be a gift from heaven and the film's narrative consists largely of the recurring motif of this Muslim man reluctantly rescuing various "damsels in distress". First he prevents a woman named Edda (Tiina Tauraite) who is apparently suffering from deep depression due to the lack of male attention from committing suicide by shooting herself. Later he has sex with a horny psychiatrist Hildegard (Katariina Lauk), who is working at the asylum and unceremoniously asks him to inspect her genitals. For his sexual service, he is paid with striped socks, maybe a sign that he is being treated like a drone - good only for providing sperm. (Figure 10) As if to confirm this diagnosis, Hildegard later tells him on the phone that his sperm proved to be of good quality and can be used for insemination. Even the army that the veteran encounters during his journey includes women. While the women that Kirotaja meets tend to be armed and eager to use their weapons, Kirotaja is hostile to guns. He does not use guns nor does he like others to use guns, despite being a trained sniper. It is also suggested that one of the women that he meets plants a gun in his suitcase, most likely to frame him as a killer of her husband. Such a plot can be seen as a metaphor of the use of Muslims as scapegoats, made responsible for any crimes perpetuated by the West.

The deficit and emasculation of men in Estonia might be an allusion to the fact that this country has lost much of its menfolk in military conflicts; as a consequence of being a small nation, squeezed between larger countries, such as Russia, Germany, and Poland that have used it as an arena to play out their imperial ambitions or, as in the case of the war in Afghanistan, as cannon fodder in conflicts taking place elsewhere. It can also be seen as a statement about a more general crisis of masculinity, which affected men in both the East and in the West following deindustrialisation, but has an especially strong effect on men from the ex-Soviet Union, as is proven by their low life expectancy caused by high rates of accidents, alcoholism, and suicide. Against this background, Afghanistan, despite its reputation as one of the most dangerous countries in the world, turns out to be a place where a man can remain a man: preserve his life, virility, and dignity. Perhaps Kirotaja ultimately chooses Afghanistan because subconsciously he knows that his manhood is "safer" in his new country than in his old one. By the same token, it is argued that the film has an anti-modernist agenda, most apparent in Keedus's critiques of contemporary art (see Oja 2011: 90), although conveyed in a subtler way than in A Moslem.

While Afghanistan is one of the most religious countries in the world, Estonia is described as the most secular and Keedus's film corroborates this fact. The only person seen praying in Letters to Angel is Kirotaja. The spaces and times devoted to religious rites have been occupied by art. Almost every person is involved with art - singing, playing a musical instrument, acting. The most conspicuous case of engagement with art is the preparations for a performance in which naked women play angels; this appears to be a feminist spectacle prepared by a well-known lesbian artist Lovely Laabus (Katrin Saukas). The second time this performance takes place in a church, dur- 
ing the funeral of Kirotaja's father, clearly annoying the mourner, who regards such an intervention as completely unsuitable to the sombre occasion. (Figure 11) Although many people engage in artistic endeavours, these seem solely directed at the artists, rather than the audiences. Significantly, all the performances Kirotaja witnesses have no viewers except himself who appears to be merely an accidental spectator.?

Although in Estonia, Kirotaja is greeted with sympathy or even enthusiasm, he does not strike up any friendships, but instead remains a solitary figure, emotionally disengaged from everybody and everything he experiences. His loneliness and selfcontainment is epitomised by the "letters to angel" that he writes in Afghanistan and Estonia. Ostensibly the addressee of these letters is his daughter whom he has never met, and only spoken to once over the telephone, but they fulfil the function of a diary, allowing the veteran to fill the void resulting from his inability or unwillingness to communicate with other people. His reticence can be regarded as symptomatic of Islam's distrust of the Western world, resulting from the conviction that the words of Muslims will be misrepresented, therefore it is better to keep silent than to engage in a dialogue on the enemy's terms; not unlike what we witness in Essential Killing. However, the women that Kirotaja meets are interested in his letters and some even want him to write letters to them as opposed to the absent or immaterial angel, which might symbolise a desire to break the impasse between Islam and the Western world and overcome what Samuel Huntington describes as the "clash of civilisation" (Huntington 1996). The film finishes with the image of Kirotaja walking in a deserted landscape, in fog or a cloud created by sand. The image is more optimistic than the one offered by Skolimowski, in which the Muslim fighter is wounded and sentenced to death, but both signify the unknown future and continuous isolation of
Muslims, both on their own territory and in foreign lands.

\section{CONCLUSION}

These films deal with the problems inherent in their local societies, with the tensions explicitly expressed as a conflict between local and global structures. This conflict is triggered, or made more visible, by the presence of the Muslim convert. In other words, the converts ignite a process, in which the local identities are deterritorialised, values questioned, traditional and/or contemporary frames of references are unsettled. Furthermore, these films also deterritorialise - unhinge, problematise - the stereotypes that have become associated with Muslims in the Western world, especially after 9/11. They offer alternative images of Muslims to the negative and stereotypical images in the Western media, as well as those in the mainstream media in the countries that belonged to the Soviet bloc, but which, after the fall of communism, became allies of the United States. In the renditions by Khotinenko, Skolimowski, and Keedus, Muslims are not aggressive; if they fight, they do so in self-defence. They are not mad; it is rather the world around them that has lost its way and is subsequently deterritorialised by the heroes' return. They also come across as dignified and charismatic, attracting the interest and pity of the local population, most importantly the women, literally or metaphorically abandoned by their menfolk. They even offer them a chance of renewal. The filmmakers also represent the post-communist countries as being forced to fight the American War on Terror against their will, not unlike in the past when they had to fight in the wars serving the interest of Russia. 


\section{REFERENCES}

Agamben, Giorgio 1998. Homo Sacer: Sovereign Power and Bare Life. Trans. Daniel Heller-Roazen. Stanford: Stanford University Press.

Berghahn, Daniela; Sternberg, Claudia (eds.) 2010. European Cinema in Motion: Migrant and Diasporic Film in Contemporary Europe. Basingstoke, New York:

Palgrave Macmillan.

Beumers, Birgit 1999. 'Cinemarket, or the Russian Film Industry in "Mission Possible"'. - Europe-Asia Studies, 51, 5, 871-896.

Beumers, Birgit 2009. A History of Russian Cinema. Oxford, New York: Berg.

Brown, William; Iordanova, Dina; Torchin, Leshu (eds.) 2010. Moving People, Moving Images: Cinema and Trafficking in the New Europe. St Andrews: St Andrews Film Studies.

Butler, Alison 2002. Women's Cinema: The Contested Screen. London: Wallflower.

Coghlan, Tom 2013. 'Red Army's "ghosts" of Afghanistan'. - Islamist.com, 8 March. http://www.islamist.com/ index.php/society/2319-many-soviet-vets-becamemuslim-and-live-in-afghanistan (29 December 2013).

Coxe, Brinton Tench 2003. 'Sonic Hierarchies and the Clash of Discourse in Andrei Mikhalkov-Konchalovsky's First Teacher'. - Ulbandus: The Slavic Review of Columbia University, 7, 107-121.

Dawson, Tom 2011. 'Polish Director, Writer and Actor Jerzy Skolimowski on New Film Essential Killing. The List, 18 March. http://film.list.co.uk/article/33344polish-director-writer-and-actor-jerzy-skolimowskion-new-film-essential-killing/ (16 February 2014).

Deleuze, Gilles; Guattari, Félix [1972] 1983

Anti-Oedipus: Capitalism and Schizophrenia. Trans.

Robert Hurley, Mark Seem, Helen R. Lane. Minneapolis: University of Minnesota Press.

Deleuze, Gilles; Guattari, Félix [1975] 1986. Kafka:

Toward a Minor Literature. Theory and History of

Literature 30. Trans. Dana Polan. Minneapolis, London:

University of Minnesota Press.

Deleuze, Gilles; Guattari, Félix [1980] 1987. A Thousand

Plateaus: Capitalism and Schizophrenia. Trans.

Brian Massumi. Minneapolis, London: University of

Minnesota Press.

Deleuze, Gilles; Guattari, Félix [1991] 1994. What /s

Philosophy? Trans. Hugh Tomlinson, Graham Burchill.

London, New York: Verso.

Дондурей, Даниил 2000. '“Вы гангстеры?” - “Нет, мы русские"'. - Искусство кино, 11. http://kinoart.ru/ru/ archive/2000/11/n11-article16 (27 February 2014).

Engelen, Leen; Van Heuckelom, Kris (eds.) 2014. European Cinema after the Wall: Screening East-West Mobility. Lanham, Plymouth: Rowman and Littlefield. Franklin, Anna 2010. 'FNE Venice IFF 2010: Interview with Jerzy Skolimowski'. - Filmneweurope.com http://www.filmneweurope.com/news/poland/6130fne-venice-iff-2010-interview-with-jerzy-skolimowski/ menu-id-158 (16 February 2014).

Gillespie, David 2003. Russian Cinema. Harlow: Pearson Education Limited.

van Gorp, Jasmijn 2012. 'National Identities in

Post-9/11 Transnational Cinema'. - Lars Kristensen (ed.), Post-communist Film - Russia, Eastern Europe and World Culture: Moving Images of Postcommunism London, New York: Routledge, 13-23.

Gott, Michael 2014. 'West/East Crossing: Positive Travel in Post-1989 French-language Cinema'. - Leen Engelen, Kris Van Heuckelom (eds.), European Cinema after the Wall: Screening East-West Mobility. Lanham, Plymouth: Rowman and Littlefield, 1-18.

Graffy, Julian 1996. 'Everything Will Be O.K.:- Sight and Sound, 6, 10, 24-25.

Hardt, Michael; Negri, Antonio 2006. Multitude: War and Democracy in the Age of Empire. London: Penguin. Harvey, David 2006. The Limits to Capital. New and fully updated edition. London: Verso.
Hashamova, Yana 2007. Pride and Panic: Russian Imagination of the West in Post-Soviet Russian Film. Bristol: Intellect.

Holland, Eugene W. 1999. Deleuze and Guattari's Anti-Oedipus: Introduction to Schizoanalysis. London, New York: Routledge.

Huntington, Samuel P. 1996. The Clash of Civilizations: And the Remaking of World Order. New York: Simon \& Schuster.

Johnson, Vida T. 1997. 'The Search for a New Russia in an "Era of Few Films"'. - The Russian Review, 56, 2, 281-285.

Jäckel, Anne 1997. 'Cultural Cooperation in Europe: The Case of British and French Cinematographic Co-production with Central and Eastern Europe.. Media, Culture \& Society, 19, 111-120.

Kean, Thomas H.; Hamilton, Lee H.; Ben-Veniste, Richard; Kerrey, Bob; Fielding Fred F.; Lehman, John F.; Gorelick, Jamie S.; Roemer, Timothy J.; Gorton, Slade; Thompson, James R. s.a.. The 9/11 Commission Report: Final Report of the National Commission on Terrorist Attacks Upon the United States. http://www.gpo.gov/ fdsys/pkg/GPO-911REPORT/pdf/GPO-911REPORT.pdf (24 February 2014).

Ladegaard, Jakob 2013. 'On the Frontier of Politics: Ideology and the Western in Jerzy Skolimowski's Essential Killing and Jim Jarmusch's Dead Man'. Studies in Eastern European Cinema, 4, 2, 181-197. Lawton, Anna 2004. Imaging Russia 2000: Film and Facts. Washington: New Academia Publishing. Loomba, Ania 1998. Colonialism/Postcolonialism. London, New York: Routledge.

Loshitzky, Yosefa 2010. Screening Strangers: Migration and Diaspora in Contemporary European Cinema.

Bloomington and Indianapolis: Indiana University Press. Ludewig, Alexandra [forthcoming]. 'Salami Aleikum -

The "Near East" Meets the "Middle East" in Central Europe'. - Michael Gott, Todd Herzog (eds.), East, West and Centre: Mapping Post-1989 European Cinema. Edinburgh: Edinburgh University Press.

Martin-Jones, David 2006. Deleuze, Cinema and National Identity: Narrative Time in National Contexts. Edinburgh: Edinburgh University Press.

Mazierska, Ewa 2010. Jerzy Skolimowski: The Cinema of a Nonconformist. New York, Oxford: Berghahn Books.

Mazierska, Ewa 2014. 'Framing a Terrorist: The Politics of Representation in Ici et ailleurs (1970-1974), Four Lions (2010), and Essential Killing (2010)'. - Framework, $55,1,102-120$.

Mazierska, Ewa; Kristensen, Lars; Näripea, Eva 2014. 'Introduction: Postcolonial Theory and the Postcommunist World'. - Ewa Mazierska, Lars Kristensen, Eva Näripea (eds.), Postcolonial Approaches to Eastern European Cinema: Portraying Neighbours on Screen. London: I.B.Tauris, 1-39.

Mazierska, Ewa; Rascaroli, Laura 2006. Crossing New Europe: Postmodern Travel and the European Road Movie. London: Wallflower Press.

Mitchell, Jolyon 2008. 'Portraying Religion and Peace in Russian Film'. - Studies in World Christianity, 14, 2 , 142-152.

Naficy, Hamid 2001. An Accented Cinema: Exilic and Diasporic Filmmaking. Princeton: Princeton University Press. Nawój, Ewa 2014. JJerzy Skolimowski'. - Culture.pl. http://culture.pl/en/artist/jerzy-skolimowski\#kill'em all (24 February 2014)

Norris, Stephen M. 2012. Blockbuster History in the New Russia: Movies, Memory, and Patriotism. Bloomington: Indiana University Press.

Oja, Martin 2011. 'Pragunevate simulaakrumite linn'. Teater. Muusika. Kino, 4, 87-92.

Orgad, Shani 2012. Media Representation and the Global Imagination. Cambridge: Polity Press.

Ostrowska, Elzibieta 2011. 'Desiring the Other:

The Ambivalent Polish Self in Novel and Film. - Slavic Review, 70, 3, 503-523. 
Parr, Adrian 2010. 'Deterritorialisation/Reterritorialisation'. - Adrian Parr (ed.), The Deleuze Dictionary. Revised edition. Edinburgh: Edinburgh University Press, 69-72. Pekerman, Serazer 2012. 'Representations of Former USSR and Eastern European Identity in Turkish Cinema'. - Lars Kristensen (ed.), Post-communist Film - Russia, Eastern Europe and World Culture: Moving Images of Postcommunism. London, New York: Routledge, 171-182.

Rodowick, David 1997. Gilles Deleuze's Time Machine. Durham, London: Duke University Press.

Said, Edward W. 1978. Orientalism. New York: Vintage Books.

Shaikh, Nermeen 2013. 'Barnett Rubin on the Soviet Invasion of Afghanistan and the Rise of the Taliban. Asia Society. http://asiasociety.org/policy/

strategic-challenges/intra-asia/barnett-rubinsoviet-invasion-afghanistan-and-rise-taliban (28 December 2013).

Sutton, Damian; Martin-Jones, David 2008.

Deleuze Reframed. London, New York: I.B.Tauris.

Swaffar, Janet 2000. 'Identity Signifiers in

Contemporary Russian Films: A Lacanian Analysis'. American Imago, 57, 1, 95-119.

Tradigo, Alfredo 2006. Icons and Saints of the Eastern Orthodox Church. Los Angeles: Getty Publications. 